\title{
Strategies by which some Pathogenic Trichomonads integrate Diverse Signals in the Decision-making Process*
}

\author{
LUCIENE BOTTENTUIT LÓPEZ ${ }^{1}$, MARIANE BANDEIRA DE MELO BRAGA ${ }^{1}$, \\ JAIME ORTEGA LÓPEZ ${ }^{2,3}$, ROSSANA ARROYO ${ }^{2,3}$ and \\ FERNANDO COSTA E SILVA FILHO ${ }^{1,2 * *}$ \\ ${ }^{1}$ UFRJ-Instituto de Biofísica Carlos Chagas Filho, Ilha do Fundão - 21949-900 Rio de Janeiro, Brazil \\ ${ }^{2}$ CICATA (PIBIOM) del Instituto Politecnico Nacional, CP 11500, México, DF. \\ ${ }^{3}$ CINVESTAV del Instituto Politecnico Nacional, Apto. Postal 14-740, CP 07360, México, DF. \\ Manuscript received on February 4, 2000; accepted for publication on February 8, 2000; \\ contributed by Fernando Costa e Silva Filho
}

\begin{abstract}
The interaction between each one of Trichomonas vaginalis and Tritrichomonas foetus with their hosts is a complex process in which components associated to the cell surfaces of both parasites and host epithelial cells, and also to soluble components found in vaginal/urethral secretions, are involved. Either cytoadhesion or the cytotoxicity exerted by parasites to host cells can be dictated by virulence factors such as adhesins, cysteine proteinases, laminin-binding proteins, integrins, integrin-like molecules, a cell detachment factor, a pore-forming protein, and glycosidases among others. How trichomonads manipulate informations from the extracellular medium, transduce such informations, and respond to them by stimulating the activities of some surface molecules and/or releasing enzymes are the aspects concerning trichomonal virulence which are here briefly reviewed and discussed.
\end{abstract}

Key words: Trichomonas vaginalis, Tritrichomonas foetus, parasitic protozoa, host-cell parasite interaction relationships, trichomonal virulence.

\section{INTRODUCTION}

Trichomonads constitute a group of amithocondriate flagellate protozoa which are mostly parasite or comensal inhabiting oxygen-poor environments (Cavalier-Smith 1993). Parasitic trichomonads include Trichomonas vaginalis and Tritrichomonas foetus which are both aethiologic agents of the human urogenital and bovine trichomoniasis or trichomonosis, respectively (Honigberg 1978a,b).

The human urogenital trichomoniasis is one of

\footnotetext{
*Invited paper

** Member of the Academia Brasileira de Ciências

Correspondence to: Dr. Fernando Costa e Silva Filho

E-mail: fcsf@biof.ufrj.br
}

the most frequent non-viral worldwide sexual transmitted disease (STD) (Lockhart et al. 1996, World Health Organization, 1995) affecting around 180 million people (Cotch et al. 1991, Rein et al. 1990) while T. foetus is the main cause of weight loss and abortion in cattle (Yule et al. 1989).

The spectrum of clinical trichomoniasis in human ranges from asymptomatic carrier stage to flagrant vaginitis (Rein et al. 1990). The clinical significance of $T$. vaginalis infection in male urologic conditions seems to be controversial (Krieger 1981). Most of the T. vaginalis-harboring men are asymptomatic. However, it was observed a significant 
morbity caused by $T$. vaginalis in men, most commonly, urethral inflammation with non-gonococcal urethritis (Krieger 1995). As zinc is highly toxic to T. vaginalis, and prostatic fluids contains considerable amounts of such metal (Krieger 1995, Krieger \& Rein 1982) it is possible that many healthy men could be refractary to infection with $T$. vaginalis.

It is important to claim the attention that the diagnosis of trichomoniasis in men has been a subject of discussion. Most of men aged 16-22 years which were submitted to prostatic massage were positive for trichomonas tests (Saxena \& Jenkins 1991). Thus, the examination of urine sediment test routinely used for the diagnosis of trichomonas in men if not accompanied by prostatic massage may induces false results. Further, the parasite in men always search for a very poor-oxygen niche as seems to be the case of the inner regions of the male reproductive tract (Krieger 1990).

Women with acute infections usually present cervical erosion, hemorrhagic spots on the vaginal mucosa, and a mucopurulent discharge (Rein 1990). This clinical picture reveals how serious can be trichomoniasis in women. Among pregnant women $T$. vaginalis can induce preterm rupture of membranes, and also preterm birth (Cotch et al. 1991) being the parasite also able to weaken human amniochorion in in vitro conditions (Drapper et al. 1995).

Infected male partners of infected women can indeed lead to recurrent urogenital infections with T. vaginalis in women (Petrin et al. 1998). Such recurrency of $T$. vaginalis infection in women seems to be the main cause of the acute infection previously described (Guimarães Gonçalves 1992). High cure rates of infected women can be only obtained when the male partners are simultaneously treated.

T. foetus is observed in the urogenital cavity of cows being that it is able to migrate upward through the cervix and invade uterus (Honigberg 1978b). In bulls the parasite can be found from the preputial cavity until urethra, and also in deeper parts of the animal's urogenital tract. The parasite is usually found harbored in the animal's preputial cavity, and once infected bulls may harbor T. foetus throughout their lives (Yule et al. 1989).

Among infected calves it is frequent the occurence of endometritis, also accompanied by uterine, cervical, and vaginal catarrh. Since endometritis and uterine catarrh prevent fertilization affecting the regularity of the estrous cycle, most of the infected calves can remain permanently steriles.

The interaction of each one of T. vaginalis and T. foetus with the epithelium lining urogenital cavities is the initial and the crucial step to establishment of both human and bovine trichomoniasis.

The examination of both vaginal and cervical smears of women or calves may reveal cytomorphologycal alterations induced by trichomonads. The smears are tipically rich in polymorphonuclear elements, and a high number of isolated epithelial cells or whole epithelium fragments (Petrin et al. 1998). A carefully done pathological study carried out among a population of sexually promiscuous women which presented recurrent trichomoniasis have also revealed that the severity of trichomoniasis can induce cytopathological stages of dysplasia/metaplasia (Guimarães Gonçalves, 1992). These data seem to support some others which indicate the possibility of $T$. vaginalis to be directly associated to uterine cancer (Berggren 1969, Yap et al. 1995, Zhang \& Begg 1994).

Altogether these data emphasize the importance of studies dealing with the molecular mechanisms by which pathogenic trichomonads interact with host cells.

Since the 40's attempts have been done to bring at light detailed data concerning interaction between each one of the here refered trichomonads with cultured epithelial cells. As far as can ascertained, since the original descriptions of Trichomonas vaginalis and Tritrichomonas foetus, Hogue (1943) and the Honigberg's research group provided much of the groundwork on trichomonal pathogenesis. They were the pioneers in the investigation of the in vitro interaction between trichomonads and sheets formed by epithelial cells. 
The data obtained from studies carried out in in vivo as in in vitro conditions support the general idea that both $T$. vaginalis and $T$. foetus need to adhere to host cells in order to exert their cytopathic effects. However, the possibility of both pathogenic trichomonads to exert their cytotoxicity activities on cultured epithelial cells without cytoadherence deserves to be considered since secreted and released products by the parasites, mainly glycosidases (Silva Filho \& de Souza 1988, Silva Filho et al. 1986) and a cell-detaching factor (Garber et al. 1989) into both acellular and cellular culture media have been shown to be highly toxic to some epithelial cells.

Even carefully done, much of the studies focusing the host cell-pathogenic trichomonads interaction relationships carried out during the last 25 years at different laboratories produced data which seem to be conflictive, and in some cases diametrically opposite. This apparent discrepancy may be related much more to the strains of the parasites as well as the epithelial cells used during the experiments than to remarkable different points of view from the authors.

Fresh isolates of $T$. vaginalis that are mantained just after axenization as stabilates, and subsequently cloned comprise very different populations of the parasite (Fattel Facenda 1997). A highly virulent Mexican strain of T. vaginalis named CNCD 147 is represented by subpopulations ranged from very low to high degrees of virulence. Two of such subpopulations -MXL-411, and MXL-5213- are completely different in morphological, cytoadherence, and cytotoxicity terms (Fattel Facenda 1997) and may be also different in terms of the occurence of cytoplasmic RNA-viruses (Wang et al. 1987). These data strongly suggest (a) the possibility of the selection of a $T$. vaginalis population during a particular experiment, and that (b) the concept of strain in T. vaginalis needs to be carefully considered or still it should be further revised.

Epithelial and also non-epithelial cells have been used in studies concerning pathogenic trichomonads-host cell interaction relationships.
The epithelial cell lineages used in such studies include WISH (Martinotti et al. 1986), HeLa (Alderete \& Pearlman 1984), MDCK (Silva Filho $\&$ de Souza 1988), and sheets formed by each one of human (Arroyo et al. 1993) and bovine (Singh et al. 1999) vaginal epithelial cells among others. However, excepting MDCK cells, no studies concerning determination of some basic biological and biophysical parameters are available on most of the in vitro epithelial models used for interaction with pathogenic trichomonads. Thus, even apparently forming monolayers or spots of cell sheets on inert surfaces we still do not know if these cells present, for instance, electrical resistance comparable to that observed in in vivo conditions. From such inference it is reasonable to consider that experiments carried out with different strains or clones of the trichomonads concomitantly with different cultured epithelial cells might result in the previously refered discrepancies.

However, all the authors have shown that either T. vaginalis as T. foetus are able to damage sheets or monolayers formed by all the assayed epithelial cells (Alderete \& Pearlman 1984, Krieger et al. 1985, Rasmussen et al. 1986, Silva Filho \& de Souza 1988).

After a basic characterization of the in vitro behavior of human or bovine vaginal epithelial cells they will obviously be the appropriate cellular models to study the host cell-T. vaginalis or T. foetus interactions, since the chemical composition of the apical surface-facing parasites in epithelial cells greatly varies according to the organs or tracts from which they have been obtained.

It has been pointed out that the cytoadhesion is a key property to the colonization and infection of T. vaginalis (Alderete \& Garza 1985), and probably also T. foetus (Silva Filho \& de Souza 1988). Trichomonal cytoadhesion is a highly specific event where molecules associated to both parasites and host cells, and also to some host soluble molecules found in vaginal/urethral secretions, are involved. The components displayed on the cell surface of the 
parasites plays important roles in cytoadhesion.

Nonetheless, the knowledgement of the parasite and the host epithelial cell surface molecular repertoires is of relevance.

\section{RECOGNIZING THE EPITHELIAL CELL SURFACE}

Trichomonal cytoadhesion like other cell-cell interaction processes is a very complex phenomenon which is always preceeded by cellular recognition. The last is in turn, governed by electrotrostatic, van der Waals, and Lewis acid-base interactions (see van Oss 1994). It means that short and long-range forces generated into the interaction media may reduce/prevent or impulse the mutual interaction between the surfaces of pathogenic trichomonads and the epithelial cells.

Either pathogenic trichomonads or the apical domain of epithelial cells possess negatively charged surfaces, being that much of such surface negativeness comes from the ionization of carboxyl groups from sialic acids residues, and phosphates from phospholipds susceptible to treatment with phospholipase C (Silva Filho et al. 1986). In addition, the cell surface of pathogenic trichomonads is hydrophobic (Bonilha et al. 1992). Therefore, either modulation of the exposition of sialic acid residues as well as expulsion of water of hydration (van Oss 1997) are necessaries to the parasites to approach the epithelial cell surface. The presence of both endogenous neuraminidase and phospholipase activities (Silva Filho et al. 1989) in trichomonads may be related to the ability of the parasites to contact the epithelial cell surface to distances below 30 nm (van Oss 1994).

Both T. vaginalis and T. foetus when found in axenic cultures tend to be uniform in shape. A pear or oval shape is predominantly observed among microorganisms swimming into culture medium. By contrast, rounded and ameboid forms of $T$. vaginalis are found among parasites attached to the culture tubes walls, and mainly among those found adhered on sheets formed by vaginal epithelial cells (VEC) (Arroyo et al. 1993).
Treatment of the parasites with depolymerizing agents of microfilaments such as the cytochalasins $\mathrm{B}$ or $\mathrm{D}$ induces a high inhibition of the attachment of T. vaginalis to inert surfaces (Silva Filho et al. 1987). These cytoplasmic expansions performed by the parasites are indeed essential to the parasites to remain attached to glass or plastic surfaces (Bonilha et al. 1992) as well as to adhere onto epithelial monolayers formed by MDCK cells (Silva Filho \& de Souza 1988).

Taking into account the hydrophilicity of the media where the mutual interaction of trichomonads with host cells takes place, and the electrostatic barrier generated between the two interacting surfaces, the presence of pseudopods and/or fillopodia in $T$. vaginalis should represent a very efficient mechanism displayed by the parasite to contact the epithelial surface. Through the emission of thin pseudopods much of the interstitial water surrounding the parasite could become expelled.

Although this mechanism could be not easy to imagine intuitively by some parasitologists and microbiologists, one may picture the process as a squeezing action, exerted by surrounding, partly hydrogen-bounded water molecules, on the hydrophobic molecules or particles in the midst. Similar to what occurs during the bacteria-phagocyte interaction (van Oss et al. 1975), by means of its neuraminidase and/or phospholipase activitities $T$. vaginalis could reduce its surface negativeness, and by means of the emission of pseudopods it could improve an efficient way to ensure its contact with host cells or with other microorganisms, as seems to be the case of the interaction between erythrocytes and bacteria and T.vaginalis (Rendón-Maldonado et al. 1998).

Further, the movement of the five flagella easily found in pear-shaped trophozoytes of $T$. vaginalis and the four ones found in T. foetus trophozoytes are of importance not only to the locomotion of the parasite into liquid media but also to the induction of liquid currents that become parasites able to easily uptake nutrients from the surround- 
ing medium. It is important to claim the attention that, as clearly demonstrated to the function of cillia in some prokaryotic cells, flagellar movement of pathogenic trichomonads seems to be not enough to ensure the approaching of the parasites to cell monolayers. The interfacial forces residing in the bulk solution must be indeed considered in order to provide knowledge on how to manipulate host environment to hamper the recognition of the host epithelial cells by pathogenic trichomonads.

Little is still known on the surface components of epithelial cells involved in their recognition by the here cited trichomonads. Some glycoconjugates of the apical domain of MDCK-I cell surfaces are the candidates to be recognized by both trichomonads, meanly by T. foetus (Bonilha et al. 1995). On the other hand, lectin molecules found at the cell surface of trichomonads appear to be important to the epithelial cell recognition by these trichomonads (Babál \& Russel 1999). It means that the recognition of the host epithelial cells by both $T$. vaginalis and T. foetus may be partially related to some parasitic surface lectins.

\section{ADHERING TO THE EPITHELIAL CELLS}

It was clearly demonstrated by the Alderete's research group that two classes of molecules at least are directly implicated in the adhesion of $T$. vaginalis to both VEC and HeLa cells. One of these molecules class was named adhesin (Alderete et al. 1995), and the other one is represented by cysteine proteinases (Arroyo \& Alderete 1989). The following four adhesins (APs) have been identified in $T$. vaginalis: AP65, AP51, AP33 and AP23 (Arroyo et al. 1992). Recently, the Arroyo's group identified a $120 \mathrm{kDa}$ surface protein in T. vaginalis that may be a new adhesin (Yañez-Gómez 1999).

The ap 65-1, ap 65-2, and the ap 65-3 genes are present within $T$. vaginalis genome in multiple copies. Interestingly, the isoforms 1, 2, and 3 of the AP 65 exibit significant homology to the hydrogenosomal malic enzyme (Hrdý \& Müller 1995) either at amino acid as nucleotide levels (Alderete et al.
1995, O’Brien et al. 1996). As previously pointed out (O'Brien et al. 1996) there is the possibility of gene sharing (Piatigorsky \& Wistow 1989) in $T$. vaginalis. The possibility of the occurrence of gene sharing as well as multifunctional surface proteins in pathogenic trichomonads and other parasitic protozoa constitute very exciting areas to be explored.

The expression of APs on the cell surface of $T$. vaginalis is alternate with the expression of $\mathrm{P} 270$ which is a highly immunogenic protein (Alderete 1988). This alternance in the expression of these known surface markers of $T$. vaginalis seems to be related to a mechanism displayed by the parasite to its evasion from the immune system.

At least in $T$. vaginalis both adhesins and surface proteinases activities may be functionally associated since CP activity is required to parasite adhesion to HeLa cell monolayers. Multiple activities of cysteine proteinases have been found among parasitic protozoa (North et al. 1990) including $T$. foetus (Mallinson et al. 1995). However the CPs in $T$. foetus are much associated to the cytotoxicity exerted by the parasite to cultured epithelial cells rather than cytoadhesion (Silva Filho \& de Souza 1988, Melo Braga 2000). Recently it was observed in $T$. vaginalis a relationship between a $65 \mathrm{kDa}$ proteinase whose activity could be inhibited by E-64, and the ability of the parasite to damage HeLa cell monolayers (Alvarez-Sánchez et al. 2000).

Trichomonal adhesins are much more than "biological glues". Their syntheses are greatly enhanced as soon as T. vaginalis contacts HeLa cell monolayers VEC (Arroyo et al. 1993). It means that there is a specific signalling for ameboid transformation in the parasite that is started during the binding of adhesins to their partners residing at the epithelial cell surface. The possibility of CP activities to be initially implicated in the modulation of the exposition of cell surface components in $T$. vaginalis, and the resulting exposition of new surface glycoconjugates residues to be triggers for the signalling of adhesin synthesis seems to be a very interesting subject. 
Based on some cytochemical (Benchimol et al. 1986) and physico-chemical (Silva Filho \& de Souza 1986, Silva Filho et al. 1986) findings on the trichomonal cell surface it is possible to infer that the plasma membrane of $T$. vaginalis and mainly of $T$. foetus possesses a considerable level of fluidity.

Taking into account the membrane fluidity in $T$. vaginalis it is reasonable to think the occurrence of patching and capping of adhesin molecules during the cytoadhesion of the parasite to cultured epithelial cells. It is possible that when the cytoadhesion just begins the adhesins might be found distributed over the entire cell surface of $T$. vaginalis, and when the process is entirely completed the adhesins might be preferentially located at pseudopods/fillopodia of parasites spreading onto epithelial cell monolayers.

\section{SOME EXTRACELLULAR MATRIX COMPONENTS MAY TELL TRICHOMONADS WHAT THEY HAVE TO DO}

Extracellular matrix (ECM) components are secreted by cells in order to model the intercellular space. The networks formed by extracellular matrix components exert profound effects over cells. Thus, tissue homeostasis is intimaly related to the extracellular matrix organization.

Both laminins and fibronectin are ECM glycoproteins important to the maintenance of the integrity of the urogenital walls. Laminins (LMN) are trimeric molecules with eleven genetically distinct chains (Engvall \& Wewer, 1996), some of them forming the basement membrane (Tryggavsson 1993). Fibronectin (FN) is a dimeric glycoprotein (Hynes 1992a) composed by three types of multiple repeats or modules (FN 1, FN 2, and FN 3), and it is known as a prototype of adhesive glycoproteins.

The abilities of these ECM molecules to serve as substrates for cell adhesion, spreading, and migration are widely known. Moreover, putative cell adhesion sequences have been mapped to domain III of the $\alpha_{1}$, and $\alpha_{1}$ chains of laminin-1. The sequences include RGD in mouse $\alpha_{1}$, and YIGSR in mouse $\alpha_{1}$ (Yamada \& Kleinman, 1992). The RGD sequence is also found within the cell-binding domain III (region repeats 8-11) of fibronectin (Hynes 1992a).

These discrete aminoacid sequences may represent instructional informations for most of the studied prokaryotes and eukaryotes. Among pathogenic microorganisms it has been shown that some of them are able to recognize each one of the cell adhesion-binding sequences (Furtado et al. 1992, Lopes et al. 1988, Silva et al. 1999, TalamásRohana \& Meza 1988).

Either FN as LMN as well as other RGD or YIGSR containing molecules are potentially able to form molecular bridges between pathogens and host cells. Such cellular intercourse can convey a wide range of different messages to both cells. A simple touch of some cells including parasitic protozoa to each one of immobilized FN or LMN can result in drastic alterations in cellular morphology which is almost always followed by proteolytic activation (Avila \& Calderón 1993, Li et al. 1995, Vásquez et al. 1995).

By analogy to what occurs to the individuals in a society, we can state that FN or LMN can be responsible for the affection or hostility between cells. Hostility seems to be what occurs during FN or LMN-mediating cell-parasite interaction while affection can be driven by FN or LMN between healthy neighboring cells having the same embryonic origin.

A $118 \mathrm{kDa}$ surface molecule enables $T$. vaginalis and T. foetus to recognize laminin-1, and also to adhere to LMN-revested substrates (Silva Filho et al. 1988). Specific recognition of laminin-1 by $T$. vaginalis is preferentially located at YIGSR aminoacid sequence (Silva Filho et al. 1998) while FN recognition by $T$. foetus is carrried out through some mannose residues-containing glycoconjugates (Silva Filho \& de Souza 1987).

It is very important to point out that like to that observed in most of the investigated cells (Wewer \& Engvall 1994) the binding of laminin to the surface components of trichomonads is improved in the 
presence of $\mathrm{Mn}^{++}$(Wewer \& Engvall 1994) contrariously to both $\mathrm{Ca}^{++}$and $\mathrm{Mg}^{++}$which decrease the affinity of the laminin-1 receptor to its ligand. By contrast, $\mathrm{Ca}^{++}$and $\mathrm{Mg}^{++}$are essential to increase the affinity of FN receptors to the human plasma fibronectin (Hynes 1992 b).

Therefore, results obtained from experiments focusing the ECM molecules-pathogens interaction which are not well designed with respect to ion requirements could induces misinterpretations on the occurence of LMN or FN binding molecules on pathogens surfaces.

The adhesion of $T$. vaginalis to ECM molecules-covered substrates is a transient adhesion process since fibronectin at least is fully digested by trichomonal proteases (Becerril Garcia 1998, Crouch \& Alderete 1999) including the previously reported CP 65 (Alvarez-Sánchez et al. 2000). This might reflect that $T$. vaginalis is able to perform an adhesion/de-adhesion process like some phagocytes and tumor cells. Further, a highly regulated and specific protease activity which is released by trichomonds during their contacts with ECM components (Bózner \& Demes 1991) enables the parasites to invade tissues. Having T. vaginalis the necessary tools to digest ECM networks it can be predictable that the parasite can indeed perform tissue invasion. Tissue invasion by $T$. vaginalis could help to explain the presence of the parasite associated to human endocervix (Guimarães Gonçalves 1992). In addition, it would be also of interest to know whether the isoform 5 of laminin (laminin-5) that is observed at high amounts in urogenital ulcers (Klainulainen et al. 1997) plays any role in the association of $T$. vaginalis to both ecto and endocervix.

The binding of LMN to the trichomonad surface is a trigger to or it impairs the intracellular signalling yet described (Silva Filho 1998). The LMN binding to the $T$. vaginalis surface seems to be mediated much more by a laminin-binding protein (LBP) (Gee et al. 1997) rather than by an integrin (Hynes 1992b) since as previously here refered, YIGSR instead of RGD is the sequence preferentially recog- nized by the parasite to the ligand. This signalling triggering or impairing by the binding of LMN to the T. vaginalis cell surface always results in the formation of tight association sites between the parasite and LMN-covered glass slides. Such adhesion sites resemble focal adhesion processes (Otey 1996). The phosphorylation of pp125 FAK as well as activation of some components of the cell signalling cascade in T. vaginalis (Silva Filho 1999) strongly suggest that (a) the YIGSR-binding surface component in the parasite might be a transmembrane protein or (b) the LMN recognition by the parasite might be carried out by YIGSR-binding surface molecules while signalling could be triggering by an integrin or an integrin-like molecule which recognize the RGD sequence on the ligand. Since the RGD sequence of LMN can be also recognized by the parasite even at very low extent, the last hypothesis deserve to be considered.

Several eukaryotes facing LMN or FN-covered biological and non-biological substrates exibit focal adhesion processes (Otey 1996). Such very organized cytoplasmic expansions in these cell models represents sites where proteases are released.

By an analogy to that occurs in most of the investigated tumor cells it is reasonable to infer that cell signalling triggering or impairing by the binding of each one of LMN or FN on T. vaginalis cell surface could result in the formation of specific foccus to proteases releasing.

\section{IRON IS AN ESSENTIAL NUTRIENT FOR TRICHOMONADS}

Much of the data yet available on trichomonal virulence seems to point out that parasitism in trichomonads is an iron-dependent phenomenon.

The role played by iron in infections has been extensively revised (Weinberg \& Weinberg, 1995). In the case of microorganisms which are found inhabiting environments of low redox potentials, iron has a pivotal role not only to the surveillance of these microorganisms as well as to the molecular expression of their virulence markers. In addition, 
the defense mechanisms displayed by trichomonads against oxidative stress generated by superoxide radicals are centered on superoxide dismutase (SOD) activities (Kitchner et al. 1994, Lindmark \& Müller 1974). All the SOD found in trichomonads have iron as cofactor (Viscogliosi et al. 1996).

Of clinical significance is the competition established between microorganisms and also between microorganisms and the epithelium lining cavities for iron. It was observed many years ago that the iron content of the skin may enhance the susceptibility of humans to some fungal infections (King et al. 1965). Thus, the ability of cavitary microorganisms to acquire iron as well as the intracellular fate of its uptake still are highly relevant opened questions.

At first sight the iron sources available for $T$. vaginalis and $T$. foetus into hosts are restricted to some proteins (transferrin and lactoferrin, mainly) (Peterson \& Alderete 1984, Tachezy et al. 1996) and red blood cells (Dailey \& Alderete 1990, Krieger 1995). However, the squamous epithelial wall of the human vaginal cavity has an iron content which varies throughout the hormonal cycle of the host. Upon treatment with estradiol, epithelial cells became much more adherent to T. vaginalis, and also they became a very attractive target to parasite phagocytosis (Silva Filho \& Bonilha 1992). These data suggest that epithelial cells may be another source of iron for T. vaginalis.

Lysis of red blood cells has been suggested by some authors as a mechanism of iron uptake by T. vaginalis (Lehker et al. 1990). Human red blood cells can be phagocyted by pathogenic trichomonads (Rendón-Maldonado et al. 1998) probably as an attempt of the parasite to acquire iron from haemoglobin. Haemolysis by T. vaginalis may also be mediated by the insertion of pores on the red blood cell plasma membrane, being that such porin activity is inhibited by EDTA (Fiori et al. 1996).

One of the mechanisms for iron uptake used by both $T$. vaginalis and $T$. foetus involves respectively binding of the iron-carrying proteins lactoferrin and transferrin to high affinity cell surface recep- tors (Lehker \& Alderete 1992, Tachezy et al. 1996).

However, little is still known on the transferrin and lactoferrin receptors of trichomonads. It seems obvious that transferrin receptors in $T$. foetus are the same to that fully studied in metazoa: a type II membrane protein, with an N-terminal cytoplasmic domais of 61 aminoacids, a 28 aminoacids transmembrane region and a 671 aminoacids extracellular region which is glycosilated at $\mathrm{Asn}^{727}$ (da Silva et al. 1996). Interestingly, the $\alpha_{3} \beta_{1}$ integrin involved in the recognition and binding to laminin1 is a transferrin receptor which is usually found in prostatic-carcinoma cells (Coppolino et al. 1995). Further, the conserved RGD aminoacid sequence found within FN and LMN polypeptide chains has also been found in transferrin receptors from human, mouse, rat, Chinese hamster, and chicken (Dubljevic et al. 1999).

These data reinforce what we have stressed on the possibility of a trichomonad surface molecule to exert more than one function. Evidences have been accumulated on the multifunctionality of various cell surface molecules. What we have named as LBP, integrin-like molecule, adhesin, and also surface $\mathrm{CP}$ of trichomonads, might be only two or three chemical entities presenting different functional sites. Depending of what signal is received by pathogenic trichomonads from the host environment the parasites might reveal one functional site within a surface molecule which might be in turn, unrevealed in the absence of the appropriate signal.

As clearly demonstrated by the Arroyo's group the $120 \mathrm{kDa}$ surface protein of $T$. vaginalis is only detected in parasites that had been obtained from cultivation in acellular medium supplemented with high iron amounts (Yañez-Gómez, 1999). Whether iron is important to gene activation of this protein or the protein pre-exists at the cell surface being iron a cofactor to reveal its functionality needs to be answered.

Iron transporters are found in mammalian cells (Eide 1997) and in Saccharomyces cerevisae (Eide 1998), and they are often important for the home- 
ostasis of such eukaryotes. These iron transporters surface proteins are easily detected in cells collected from cultures permanently exposed to high iron amounts. These data seem to indicate that a surface glycoprotein with iron-transporter function is revealed when the ion to be dislocated from outside to inside is in excess in the extracellular medium. If this argument has consistency it would be expected that the $120 \mathrm{kDa}$ surface protein of $T$. vaginalis could also be related to iron transport beside to be an adhesin.

Iron uptake by $T$. vaginalis (Peterson \& Alderete 1984) and by T. foetus (Melo Braga 2000) modulates the functionalities of both adhesins and surface CPs, interfering with the ability of these trichomonads to adhere and to exert their cytopathic effects. However, as previously observed by Arroyo $\&$ Alderete (1995) iron has a positive regulation for adhesins while it has a negative regulation for surface CPs (Fattel-Facenda 1999). It means that the same extracellular signal can induce different detectable responses at the $T$. vaginalis surface.

\section{CONCLUSIONS}

Even investigated since the 40's we are just beginning to understand the basic mechanisms underlying trichomonal virulence. A great deal has been learned about the molecular composition of the cell surface of pathogenic trichomonads including details of functional aspects of some surface molecules. This appears to correlate with the abilities of both T. vaginalis and T. foetus to cytoadhere and also to exert their cytotoxicities to cultured epithelial cells. Currently, less is known about the epithelial surface molecules which upon or not intervenience of some soluble factors found into host urogenital cavities are recognized by the parasites. Fortunately, many of the necessary tools are at hand, and it is expected that rapid progress will be made in answering these remaining questions.

A detailed characterization of the interactions between extracellular matrix components and pathogenic trichomonads including a chemical study of the receptors, the role played by iron on the functionality of such surface molecules, and the intracellular pathways associated with the trichomonal responses to laminins, fibronectin, and some collagen species, should provide an additional exciting area of research over the next few years.

\section{ACKNOWLEDGMENTS}

Two of us (FCSF and RA) are deeply gratefull to all undergraduate and graduate students of our labs as well as to many people from other labs and academic institutions who spent much of their time to contribute so much to the discussions concerning some of our experimental data.

Thanks to FAPERJ, CNPq, FUJB-UFRJ, and MCT-PRONEX from Brazil, CONACYT from Mexico (grants 0579P-N and 25572-N), The TWAS from Italy, and also to The Volkswagen Foundation from Germany for providing us with financial supports during the last years.

\section{REFERENCES}

AlDERETE JF. 1988. Alternating phenotype expression of Trichomonas vaginalis surface markers. Ver Infect Dis 10(suppl 2): S408-S412.

Alderete JF \& Garza G. 1985. Specific nature of Trichomonas vaginalis parasitism of the host cell surfaces. Infect Immun 50: 701-708.

Alderete JF, Lehker MD \& Arroyo R. 1995. The mechanism and molecules involved in cytoadherence and pathogenesis of Trichomonas vaginalis. Parasitol Today 11: 70-74.

Alderete JF, O’Brien JL, Arroyo R, Engbring JA, Musatova O, Lopez O, Lauriano C \& Nguyen J. 1995. Cloning and molecular characterization of two genes encoding adhesion proteins involved in Trichomonas vaginalis cytoadherence. Mol Microbiol 17: 69-83.

Alderete JF \& Pearlman E. 1984. Pathogenic Trichomonas vaginalis cytotoxicity to cell culture monolayers. Brit J Ven Dis 60: 99-105. 
Alvarez-Sánchez ME, Avila González L, Becerril Garcia C, Fattel-Facenda L, Ortega-López J \& Arroyo R. 2000. A novel cysteine proteinase (CP65) of Trichomonas vaginalis involved in cytotoxicity. Mol Microbiol, in press.

Arroyo R \& Alderete JF. 1989. Trichomonas vaginalis surface proteinase activity is necessary for parasitism adherence to epithelial cells. Infect Immun 57: 2991 2997.

Arroyo R \& Alderete JF. 1995. Biología molecular de Trichomonas vaginalis. Avan Persp 14: 48-58.

Arroyo R, Engbring J \& Alderete JF. 1992. Molecular basis of host epithelial cell recognition by Trichomonas vaginalis. Mol Microbiol 6: 853-862.

Arroyo R, González-Robles A, Martínez-Palomo A \& Alderete JF. 1993. Signalling of Trichomonas vaginalis for amoeboid transformation and adhesin synthesis follows cytoadherence. Mol Microbiol 7: 299-309.

Avila EE \& Calderón J. 1993. Entamoeba histolytica trophozoytes: a surface-associated cysteine proteinase. Exp Parasitol 76: 232-241.

BabÁL P \& RusSEl LC. 1999. Sialic acid-specific lectinmediated adhesion of Tritrichomonas foetus and Tritrichomonas mobiliensis. J Parasitol 85: 33-40.

Benchimol M, Elias CA \& de Souza W. 1986. Tritrichomonas foetus: ultrastructure and cytochemistry of endocytosis. Exp Parasitol 62: 405-415.

Becerril-García C. 1998. Proteínas de matriz extracelular: ¿ Sustratos naturales de las cistein proteinasas CP30 y CP65 de Trichomonas vaginalis? Mexico, 77p. Tesis (Maestria), Instituto Politécnico Nacional, Centro de Investigacíon y de Estudios Avanzados (CINVESTAN-IPN).

BergGren O. 1969. Association of carcinoma of the uterine cervix and Trichomonas vaginalis infestations. Frequency of Trichomonas vaginalis in preinvasive and invasive cervical carcinoma. Am J Obstet Gynecol 105: 166-168.

Bonilha VL, Saraiva EB \& Silva Filho FC. 1992. Effect of a phorbol ester on basic surface properties of trichomonads. Cell Biophys 20: 1-15.

Bonilha VL, Ciavaglia MC, de Souza W \& Silva FILHo FC. 1995. The involvement of terminal carbohydrates of the mammalian cell surface in the cytoadhesion of trichomonads. Parasitol Res 81: 121-126.

Bózner P \& Demes P. 1991. Degradation of collagen types I, III, IV and V by extracellular proteinase of an oral flagellate Trichomonas tenax. Arch Oral Biol 36: $765-770$.

Cavalier-Smith T. 1993. Kingdon protozoa and its 18 phyla. Microbiol Rev 57: 953-994.

Coppolino M, Migliorini M, Argraves WS \& Dedhar S. 1995. Identification of a novel form of the $\alpha_{3}$ integrin subunit: covalent association with transferrin receptor. Biochem J 306: 129-134.

Cotch MF, Pastorek JG, Nugent RP, Hillier SL, Gibbs RS, Martin DH, Esehenbach DA, Edelman R, Carey JC, Regan JA, Krohn MA, KleBanoff NA, RaO AV \& Rhoads GG. 1997. Trichomonas vaginalis associated with low birth weight and pyeterm delivery. Sex transm Dis 24: 353-360.

Cotch MF, Pastorek JG, Nugent RP, Yeng DE, MaRTIN DH \& Eschenbach DA. 1991. Demographic and behavioral predictions of Trichomonas vaginalis infections among pregnant women. Obstet Gynecol 78: $1087-1092$

Crouch ML \& Alderete JF. 1999. Trichomonas vaginalis interactions with fibronectin and laminin. $M i-$ crobiology 145: 2835-2843.

Da Silva DM, Askwith CC \& Kaplan J. 1996. Molecular mechanisms of iron uptake in eukaryotes. Physiol Rev 76: $31-47$.

Dailey DC \& Alderete JF. 1990. Characterization of Trichomonas vaginalis haemolysis. Parasitology 101: $171-175$.

Drapper D, Jones W, Heine RP, Beutz M, French JI \& McGregor JA. 1995. Trihomonas vaginalis weakens human amminochorion in an in vitro model of premature membrane rupture. Infect Dis Obstet Gynecol 2: 267-274.

Dubljevic V, Sali A \& Goding JW. 1999. A conserved 
RGD (Arg-Gly-Asp) motif in the transferrin receptor is required for binding of transferrin. Biochem J 341: 11-14.

EIDE D. 1997. Molecular biology of iron and zinc uptake in eukaryotes. Curr Op Cell Biol 9: 573-577.

EIDE D. 1998. The molecular biology of iron transport in Saccharomyces cerevisae. Ann Ver Nutr 18: 441469.

Engvall E \& Wewer UM. 1996. Domains of laminin. J Cell Biochem 61: 493-501.

FAtTel-FaCEnda LV. 1997. Caracterización de clonas de Trichomonas vaginalis. México 52p. Tesis (Licenciatura), Universidad Nacional Autónoma de México.

FATTEL-FACENDA LV. 1999. Variación fenotipica de las cistein proteinasas CP30 y CP65 de Trichomonas vaginalis. Mexico, 67p. Tesis (Maestria), Instituto Politécnico Nacional, Centro de Investigación en Ciencia Aplicada y Tecnologia Avanzada (CICATAIPN).

Fiori PL, Rapelli P, Addis MF, Suchi A \& CAPpucCINELli P. 1996. Trichomonas vaginalis haemolysis: $\mathrm{pH}$ regulates a contact-independent mechanism based on pore forming proteins. Microb Pathogen 20: $109-118$.

Furtado GC, Slawik M, Kleinman HK \& Joiner KA. 1992. Laminin enhances binding of Toxoplasma gondii trophozoytes to $\mathbf{J 7 7 4}$ murine macrophage cells. Infect Immun 60: 2337-2342.

Garber G, Lemchuk Favel LT \& Bowie WR. 1989. Isolation of a cell-detaching factor of Trichomonas vaginalis. J Clin Microbiol 27: 1548-1555.

Gee SH, Blacher RW, Douville PJ, Provost PR, Yurchenco PD \& CARbonetTo S. 1997. Lamininbinding protein 120 from brains is closely related to the dystrophin-associated glycoprotein dystroglycan, and binds with high affinity to the major heparin binding domain of laminin. J Biol Chem 268: 14972-14980.

Guimarães Gonçalves MA. 1992. Fatores envolvidos na patogênese de Trichomonas vaginalis: estudo preliminar para o desenvolvimento de novas terapias. Rio de Janeiro 124p. Tese (Mestrado), Universidade Federal do Rio de Janeiro, Instituto de Ginecologia.

Hogue MJ. 1943. The effect of Trichomonas vaginalis on tissue-culture cells. Am J Hyg 37: 142-152.

Honigberg BM. 1978a. Trichomonads of importance in human medicine. In: KreIER JP ed., Parasitic Protozoa, vol. II, Academic Press, New York, pp. 276-454.

Honigberg NM. 1978b. Trichomonads of veterinary importance. In: KreIER JP ed., Parasitic Protozoa, vol. II, Academic Press, New York, pp. 164-273.

Hrdý I \& Müller M. 1995. Primary structure of the hydrogenosomal malic enzyme of Trichomonas vaginalis and its relationship to homologous enzymes. $J$ Euk Microbiol Microbiol 42: 593-603.

Hynes RO. 1992a. Fibronectins, pp.112, SpringerVerlag, New York.

Hynes RO. 1992b. Integrins: versatility, modulation and signalling in cell adhesion. Cell 69: 11-25.

King RD, Klan HA, Foye JC, Greenberg JI \& Jones HE. 1965. Transferrin, iron and dermatophytes. $J$ Lab Clin Med 86: 204-212.

Kitchner KR, Meshnick SR, Fairfield AS \& WANG CC. 1994. An iron-containing superoxide dismutase in Tritrichomonas foetus. Mol Biochem Parasitol 12: 95-99.

Klainulainen T, Autio-Harmainen O, Oikarinen A, Salo S, Tryggavson K \& Salo T. 1997. Altered distribution and synthesis of laminin-5 (kalinin) in oral lichen planus, epithelial dysplasias and squamous cell carcinomas. Brit J Dermatol 136: 331336.

KRIEGER JN. 1981. Urologic aspects of trichomoniasis. Invest Urol 18: 411-417.

KRIEGER JN. 1990. Epidemiology and clinical manifestations of urogenital trichomoniasis in men. In: Honigberg BM ed. Trichomonads parasitic in humans, p. 235-245, Springer-Verlag, New York.

KRIEGER JN. 1995. Trichomoniasis in men: old issues 
and new data. Sex Transm Dis 22: 83-96.

KrIEger JN \& ReIN MF. 1982. Canine prostatic secretions kill Trichomonas vaginalis. Infect Immun 37: 77-81.

Krieger JN, RAVDIN JI \& REIN MF. 1985. Contactdependent cytopathogenic mechanisms of Trichomonas vaginalis. Infect Immon 50: 778-786.

LeHKer MW \& Alderete JF. 1992. Iron regulates growth of Trichomonas vaginalis and the expression of immonogenic trichomonad proteins. Mol Microbiol 6: 123-132.

Lehker MW, Chang TH, Daily DC \& Alderete JF. 1990. Specific erythrocyte binding is an additional nutrient acquisition system for Trichomonas vaginalis. J Exp Med 171: 2165-2170.

Li E, Yang WG, Zhang T \& Stanley JR SL. 1995. Interaction of laminin with Entamoeba histolytica cystein proteinases and its effect on amebic pathogenesis. Infect Immun 63: 4150-4153.

LindMARK DG \& Müller M. 1974. Superoxide dismutase in the anaerobic flagellates, Tritrichomonas foetus and Monocercomonas sp. J Biol Chem 249: 4634-4637.

Lockhart AB, Thrall PH \& Antonovics J. 1996. Sexually transmitted diseases in animals: ecological and evolutionary implications. Biol Rev 71: 415471.

Lopes JD, Mota GFA, Carneiro CW, Gomes L, Silva Filho FC \& BRENTANi RR. 1988. Evolutionary conservation of laminin-binding proteins. Braz J Med Biol Res 21: 1269-1273.

Mallinson DJ, Livingstone J, Appleton KM, Less SJ, Coombs GH \& NorTh M. 1995. Multiple cysteine proteinases of the pathogenic protozoan Tritrichomonas foetus: identification of seven diverse and differentially expressed genes. Microbiology 141: 3077-3085.

Martinotti MG, Martinetto P \& Savoia D. 1986. Adherence of Trichomonas vaginalis to cell culture monolayers. Eur J Clin Microbiol 5: 320-323.

Melo Braga MB. 2000. A expressão de cisteíno pro- teinases em Tritrichomonas foetus é regulada por ferro. Rio de Janeiro, 72pp. Tese (Mestrado), Universidade Federal do Rio de Janeiro, Instituto de Biofísica Carlos Chagas Filho.

North MJ, Motтram JC \& Coombs GH. 1990. Cystein proteinases of parasitic protozoa. Parasitol Today 6: 270-275.

OTEY C. 1996. pp125 FAK in the focal adhesion. Int Rev Cytol 167: 161-183.

O'Brien JL, Lauriano CM \& Alderete JF. 1996. Molecular characterization of a third malic enzymelike AP65 adhesin gene involved in Trichomonas vaginalis cytoadherence. Microbiol Pathogen 20: 123.

Peterson KM \& Alderete JF. 1984. Selective acquisition of plasma proteins by Trichomonas vaginalis and human lipoprotein as a growth requirement for this species. Mol Biochem Parasitol 12: 37-48.

Petrin D, Delgaty K, Bhatt R \& Garber G. 1998. Clinical and microbiological aspects of Trichomonas vaginalis. Microbiol Rev 11: 300-317.

Piatigorsky J \& Wistow G. 1989. Enzyme/crystallins: gene sharing as an evolutionary strategy. Cell 57: 197-199.

Rasmussen SE, Nielsen MH, Lind I \& Rhodes JM. 1986. Morphological studies of the cytotoxicity of Trichomonas vaginalis to normal human vaginal epithelial cells in vitro. Genitourin Med 62: 240-246.

REIN MF. 1990. Clinical manifestations of urogenital trichomoniasis in women. In: Honigberg BM ed., Trichomonads parasite in humans, Spring-Verlag, New York, pp.225-234.

Rendón Maldonado JG, Espinoza Castellano M, González Robles A \& Martinez Palomo A. 1998. Trichomonas vaginalis: in vitro phagocytosis of lactobacilli, vaginal epithelial cells, leukocytes, and erythrocytes. Exp Parasitol 89: 241-250.

Saxena SB \& Jenkins RR. 1991. Prevalence of Trichomonas vaginalis in men at high risk for sexually transmitted diseases. Sex Transm Dis 18: 138-142.

Silva AA, Roffe E \& Lannes Vieira J. 1999. Expres- 
sion of extracellular matrix components and their receptors in the cultured nervous system during experimental Toxoplasma gondii and Trypanosoma cruzi infection. Braz J Med Biol Res 32: 593-600.

Silva Filho FC. 1998. Focal adhesion in Trichomonas vaginalis. Mem Inst Oswaldo Cruz 93 (suppl. II): 40.

Silva Filho FC. 1999. Integrins in Trichomonas vaginalis. Mem Inst Oswaldo Cruz 94 (suppl. II): 48.

Silva Filho FC \& Bonilha VL. 1992. Effect of estrogens on the adhesion of Trichomonas vaginalis to epithelial cells in vitro. Braz J Med Biol Res 25: 9-18.

Silva Filho FC \& DE Souza W. 1986. Effects of colchicine, vinblastine and cytochalasin B on cell surface anionic sites of Tritrichomonas foetus. J Protozool 33: 6-11.

Silva Filho FC \& DE Souza W. 1987. Partial lost of fibronectin-binding sites on the cell surface of trichomonads after treatment of the parasites with alpha mannosidase. Mem Inst Oswaldo Cruz 82 (suppl. I): 76.

Silva Filho FC \& De Souza W. 1988. The interaction of Trichomonas vaginalis and Tritrichomonas foetus with epithelial cells in vitro. Cell Struct Funct 13: 301-310.

Silva Filho FC, DE Souza W \& Lopes JD. 1988. Presence of laminin-binding proteins in trichomonads and their role in adhesion. Proc Natl Acad Sci USA 85: 8042-8046.

Silva Filho FC, Elias CA \& DE Souza W. 1986. Further studies on cell surface charge of various strains of Trichomonas vaginalis and Tritrichomonas foetus. Cell Biophys 8: 161-168.

Silva Filho FC, Elias CA \& de Souza W. 1987. Role of divalent cations, $\mathrm{pH}$, cytoskeleton components and surface charge on the adhesion of Trichomonas vaginalis to a polystyrene substrate. Mem Inst Oswaldo Cruz 82: 379-384.

Silva Filho FC, Ortega López J \& Arroyo R. 1998. YIGSR is the preferential laminin residing adhesion sequence for Trichomonas vaginalis. Exp Parasitol 88: $240-242$.

Silva Filho FC, Tosta MX, Saraiva EB \& de Souza W. 1989. Trichomonas vaginalis and Tritrichomonas foetus secrete neuraminidase into culture medium. Mol Biochem Parasitol 35: 73-78.

Singh BH, Lucas JJ, Beach DH, Shin ST \& Gilbert RO. 1999. Adhesion of Tritrichomonas foetus to bovine epithelial cells. Infect Immun 67: 3847-3854.

Tachezy J, Kulda J, Bah'nvoká I, Suchan P, Rázga J \& SChrével J. 1996. Tritrichomonas foetus: iron acquisition from lactoferrin and transferrin. Exp Parasitol 83: 216-228.

Talamás Rohana P \& Meza I. 1988. Interactions between pathogenic amebas and fibronectin: substrate degradation and changes in cytoskeleton organization. J Cell Biol 106: 1787-1794.

Tryggavsson K. 1993. The laminin family. Curr Op Cell Biol 5: 877-880.

VAN Oss CJ. 1994. Interfacial forces in aqueous media. p.456, Marcel Dekker, Basel.

VAN Oss CJ. 1997. Kinetics and energetics of specific intermolecular interactions. J Mol Recogn 10: 203 218.

van Oss CJ, Gillman CF \& Neumann AW. 1975. Phagocytosis as a surface phenomenum. In: VAN Oss CJ ed. Phagocytic engulfement and cell adhesiveness, 13-32 pp., Marcel Dekker, New York.

Vásquez J, Franco E, Reyes G \& Meza I. 1995. Characterization of adhesion plates induced by the interaction of Entamoeba histolytica trophozoytes with fibronectin. Cell Motil Cytoskel 32: 37-45.

Viscogliosi E, Durieux I, Delgado Viscogliosi P, Bayle D \& Dive D. 1996. Phylogenetic implication of iron-containing superoxide dismutase genes from trichomonad species. Mol Biochem Parasitol 80: $209-214$.

Wang A, Wang CC \& Alderete JF. 1987. Trichomonas vaginalis phenotipic variation occurs among trichomonads infected with double-strand RNA virus. J Exp Med 166: 142-150. 
Weinberg ED \& Weinberg GA. 1995. The role of iron in infection. Curr Op Infect Dis 8: 164-169.

Wewer UM \& Engvall E. 1994. Laminins. In: RousLahti E \& Engvall E eds. Methods in Enzymology, vol. 245, pp. 85-104, Academic Press, San Diego.

World Health Organization. 1995. An overview of selected curable sexually transmitted diseases. WHO Global Programme on AIDS Report.

Yamada K \& Kleinman R. 1992. Functional domains of cell adhesion molecules. Curr Op Cell Biol 4: 819-823.
YAÑEZ-GómEz C. 1999. Caracterización de una proteina de $120 \mathrm{kDa}$ de Trichomonas vaginalis. Mexico, 58 p., Tesis (Maestria), Instituto Politécnico Nacional, Centro de Investigación en Ciencia Aplicada y Tecnología Avanzada (CICATA-IPN).

Yap EH, Ho TH, Chan YC, Thong TW, Ng GC, Ho LC \& SINGH M. 1995. Serum antibodies to Trichomonas vaginalis in invasive cervical cancer patients. Genitour Med 71: 401-404.

Yule A, SKIRrow SZ \& BonDurant RH. 1989. Bovine trichomoniasis. Parasitol Today 5: 373-377.

Zhang Z \& BegG CB. 1994. Is Trichomonas vaginalis a cause of cervical neoplasma? Results from a combined analysis of 24 studies. Int J Epidemiol 23: 682-690. 